\title{
LEXICON
}

VOLUME 3

Number 2, October 2014

Page 104-112

\section{A STUDY OF SPEECH ACTS IN COMPUTER PRODUCTS ADVERTISEMENTS}

\author{
Adolf Richardo Bagus Setiadi
}

\begin{abstract}
This research, which is entitled "A Study of Speech Acts of Computer Products Advertisements "aims to find out the illocutionary acts that exist in computer products advertisements.

To get the results, the data were collected through library research. The data were collected from various foreign computer magazines.

The result shows that there are two patterns of illocutionary acts that exist in computer products advertisement. i.e. assertive-expressive and directive- expressive.
\end{abstract}

Keywords: illocutionary, advertisements, assertive, directive, expressive

\section{INTISARI}

Penelitian yang berjudul "A Study of Speech Acts of Computer Products Advertisements" bertujuan untuk mengetahui apa saja ilokusi yang terdapat pada iklan produk komputer. Untuk memperoleh hasil yang diinginkan, data dikumpulkan melalui metode studi pustaka. Data diperoleh dari berbagai majalah komputer asing.

Hasil yang ditemukan menyatakan bahwa terdapat dua pola ilokusi yang terdapat dalam iklan produk komputer, yaitu assertive-expressived and irective-expressive.

Kata kunci: ilokusi, iklan, assertive, directive, expressive 


\section{INTRODUCTION}

Today, promotion through media becomes a basic strategy for producers to market their products and increase their profits, and people can find it almost everywhere. They exist in magazine, newspapers, TV, even on the side of the road (billboard). They are used to tell the consumers that the products being advertised are the best choice available in the market.

Advertisements contain sentences that carry particular speech act. Speech act itself is divided into locutionary, illocutionary, and perlocutionary acts. Leech (via Justová, 2006: 11) stated that locutionary act is an act of saying something, for example: "Human has 10 fingers on his/her hands." illocutionary act is an act in saying something, for example: "Clean this room", and perlocutionary act is an act by saying something, for example: "fire!" which makes people rush out from the building.

The data that used for this research were collected from various computer products advertisements. Computer products advertisements are unique because of its diversity. Computer products advertisements include advertisements of computer and its peripheral products (monitor, RAM, printer, modem, etc.). Hundreds of new computer advertisements (due to the amount of product released) are published in various media. Thus, there are many forms of computer products advertisements, with various compositions of language, image, and other elements of advertisement.

The aims of this research are to describe the illocutionary acts that exist in the computer products advertisements.

This research was conducted based on pragmatic theory. Pragmatic is defined by Levinson (1983: 9) as "the study of those relations between language and context that are grammaticalized, or encoded in the structure of a language". In other words, pragmatic studies about meaning that is meant by the speaker (which already influenced by context) rather than the literal meaning of the word or sentence.

Several things that studied in pragmatic are deixis, implicature, presupposition, speech acts, politeness, and principles of cooperation. This paper will more focus on speech acts aspects of pragmatic. Speech act itself is defined by CARLA (2015) as an utterance that serves a function in communication.

Speech acts itself is divided by Austin (via Levinson, 1983:236) into three types, namely:

a. Locutionary act: the utterance of a sentence which determines sense and reference.

b. Illocutionary act: the making of a statement, offer, promise, etc. in uttering a sentence, by virtue of the conventional force associated with it (or with its explicit performative paraphrase).

c. Perlocutionary act: the bringing about of effects on the audience by means of uttering the sentence, such effects being special to the circumstances of utterance. Sometimes it may seem that perlocutionary acts do not differ from illocutionary acts very much, yet there is one important feature which tells them apart

In order to conduct a successful speech act, there are conditions that must be followed, which called felicity conditions. Austin(via Justová, 2006:

9) states that felicity conditions are:

a. There must exist an accepted conventional procedure having a certain conventional effect, that procedure to include the uttering of certain words by certain persons in certain circumstances.

b. The particular persons and circumstances in a given case must be appropriate for the invocation of the particular procedure invoked.

c. The procedure must be executed by all participants both correctly and completely.

d. Where, as often, the procedure is designed for use by persons having certain thoughts or feelings, or for the inauguration of certain consequential conduct on the part of any participant, then a person participating in and so invoking the procedure must intend so to conduct themselves, and further must actually so conduct themselves subsequently. 
This paper deals with illocutionary acts that exists in computer products advertisements. According to Searle (via Levinson, 1983: 240) there are five divisions of illocutionary act, namely:

a. Representatives (later will be called Assertives): A type of illocutionary act that commit the speaker to the truth of the expressed proposition, example: asserting, claiming, etc.

b. Expressives: A type of illocutionary act that express a psychological state, example: thanking, apologizing, welcoming

c. Directives: A type of illocutionary act that is used as an attempt by the speaker to get the addressee to do something, example: requesting and ordering d. Commissives: A type of illocutionary act that commit the speaker to some future course of action, for example: promising, threatening and offering

e. Declaratives: A type of illocutionary act that effect immediate changes immediate changes in the institutional state of affairs and which tend to rely on elaborate extra-linguistic institutions, for example: christening, declaring war and firing

Further, Searle and Vanderveken (1985: 179216) propose types of acts that can be carried by illocutionary act, namely:

Table 1. Acts Carried by Illocutionary Act

\begin{tabular}{|l|l|l|l|l|}
\hline \multicolumn{1}{|c|}{ Assertives } & \multicolumn{1}{|c|}{ Directives } & Commisives & \multicolumn{1}{|c|}{ Declaratives } & Expressives \\
\hline Assert & Direct & Commit & Declare & Apologize \\
\hline State & Request & Promise & Resign & Thank \\
\hline Affirm & Ask & Threaten & Adjourn & Condole \\
\hline Claim & Urge & Vow & Appoint & Congratulate \\
\hline Deny & Tell & Swear & Nominate & Complain \\
\hline Disclaim & Require/demand & Accept & Approve & Lament \\
\hline Assure & Command & Consent & Confirm & Protest \\
\hline Argue & Order & Refuse & Disapprove & Deplore \\
\hline Rebut & Forbid, prohibit & Offer & Endorse & Boast \\
\hline Inform & Enjoin & Bid & $\begin{array}{l}\text { Renounce, } \\
\text { disclaim }\end{array}$ & Compliment \\
\hline Notify & Permit & Assure & Denounce & Praise \\
\hline Remind & Suggest, insist & Guarantee & Repudiate & $\begin{array}{l}\text { Welcome, } \\
\text { greet }\end{array}$ \\
\hline Object & Warn, advise & Warrant & Bless & \\
\hline Predict & Recommend & Contract & Curse & \\
\hline Report & Beg & Covenant & Excommunicate & \\
\hline Retrodict & Supplicate & Bet & Consecrated & \\
\hline
\end{tabular}




\begin{tabular}{|l|l|l|l|l|}
\hline $\begin{array}{l}\text { Suggests, } \\
\text { insist }\end{array}$ & $\begin{array}{l}\text { Entreat, beseech, } \\
\text { implore }\end{array}$ & Pledge & Christen & \\
\hline Conjecture & Pray & & Abbreviate & \\
\hline $\begin{array}{l}\text { Hypothesize, } \\
\text { guess }\end{array}$ & & & Name, call & \\
\hline Swear & & & & \\
\hline Testify & & & & \\
\hline Admit & & & & \\
\hline Confess & & & & \\
\hline Accuse & & & & \\
\hline Blame & & & & \\
\hline Criticize & & & & \\
\hline Praise & & & & \\
\hline Complain & & & & \\
\hline Boast & & & & \\
\hline Lament & & & & \\
\hline
\end{tabular}

Searle and Vanderveken (1985: 182) state that the distinctions that can be found between those acts are:

1. The distinction between those name illocutionary force and those that do not (example: difference between order and announce)

2. The distinction between those that name conversational features in addition to illocutionary force and those that do not (example : describe pledge)

3. The distinction between those that take a performative use and those that do not (example : promise-boast)

4. The distinction between those that are essentially hearer-directed and those that do not (example: inform-state)

5. The distinction between those that name essentially public events and those that can be performed in soliloquy (example : resign conjecture)

6. The distinction between hybrids and non-hybrids (example : warn-command)

7. The distinction between illocutionary success verbs and illocutionary verbs proper (example: prove- argue)
8. The distinction between verbs that are systematically ambiguous between different illocutionary points and those that imply only one illocutionary point (example : advise - request)

This paper also deals with advertising and its effectiveness. There are several definitions of advertising. According to Tom Duncan (via Lubis, 2007), advertising is an unprivate thing, an announcement which is paid by an identifiable sponsor, while according to Arens (via Lubis, 2007), advertising is a structured communication of information that arranged not by individual, usually sponsored to persuade consumers to use particular products (goods, services, or ideas) and it is identified by the sponsors through various media.

According to TerenceA. Shimp (2003), in general, advertising has several communication functions, namely:

1). Informing

Advertisements make consumer aware of brands, educate them about features and benefit of using a product, and facilitate a good creation of a product's image. Because of its ability to reach a big number of consumer with relatively low cost, and its effectiveness in communicating, 
advertisements facilitate an introduction of new brands, increase demand for existing brands, and increase awareness of consumer to a brand. Advertisements also help existing brands to educate people about new benefit of their existing products.

2). Persuading

An effective advertisement can persuade consumer to try the goods and service being advertised. Sometimes, the persuasion can influence primary demand (create new demand for specific products from every brand), but most of the time, it will influence secondary demand (demand for a specific product from a specific brand)

3). Reminding

An advertisement will keep a brand "fresh" in the consumer's mind. Advertising will help the brand to come up the consumer's mind, and finally make thembuy the product

4). Adding Value

Advertising gives more value toward goods or services by influencing consumer's perception. Effective advertising will give an image that the product is more elegant or give more prestige compared to its competitors.

5). Assisting

One purpose of advertising is to assist companies in their efforts in marketing communication process, such as lottery, voucher giveaway, etc.

The research for this paper was conducted in Yogyakarta and Jakarta from September 5, 2014 to January 8, 2015,

For the illocutionary act investigation, the research method is:

1. Compiling various examples of advertisement from several foreign computer magazines (Computer Power User, PC Advisor, PC Gamer USA, and PC Powerplay)

2. Finding illocutionary theories for analyzing the examples through library research
3. Analyzing the data with chosen theories (Searle's illocutionary act division theory)

4. Drawing a conclusion

Due to the large amount of words and sentences that can be found in an advertisement, this research focused only on the tagline of the advertisement (which can be considered as the main part of language in the sentence). In short, elements that discussed in this paper were the illocutionary force that found in computer products advertisements.

\section{RESEARCH RESULTS AND DISCUSSION}

\section{Introduction}

There are two illocutionary force patterns that found in computer products advertisements, namely assertive-expressive and directive-expressive. The illocutionary acts here are observed based on the explicit use of word that indicates the usage of particular illocutionary acts. It should be noticed earlier that according to Searle (1985: 178), there is a law in illocution that "any illocutionary force entails an expressive force". Therefore, it can be understood that expressive illocutionary acts will be found in every example of this discussion.

\section{Types of Illocutionary Acts in Computer Products Advertisements}

\section{a. Assertive-Expressive}

From 40 advertisements that had been analyzed, 25 of them have assertive-expressive type of illocutionary acts. Three of them are explained below.

1) THE BEST PC GAMING GRAPHICS CARD ON THE PLANET (NVIDIA GEFORCE GTX 780) (PC Gamer USA, February 2014, p. 31)

This product is a product that is used in computer to help it process the graphics provided by the CPU. It is an expansion card that translates data input into graphical output that will be shown on monitor. Some functions 
of graphic card are rendering $3 \mathrm{D}$ and $2 \mathrm{D}$ picture output, TV output and MPEG-2/MPEG-4 decoding. (Nang Imam, 2014)

This advertisement uses these words (The Best.....on the Planet) to attract consumer's ego so that they will pay attention towards this product. After getting their attention, consumer is expected to buy this product because this product has advantages. Generally, people want to have best products. By using words "The Best", this advertisement tries to tell the consumer that this is the best product that they maybuy.

Assertive: The speaker's statement (The Best PC Gaming Graphic Card on the Planet) can be seen as an effort to convince the readers that this product is truly the best product that available, although there is no proof for that statement. This condition matches "claim" act, which defined by Merriam-Webster Dictionary (2015) as "to say that (something) is true when some people may say it is not true". The "claim" act is included in assertive illocutionary act, therefore it may be concluded that this sentence carries assertive illocutionary act.

Expressive: The usage of words and phrases such as "The Best" and "on the Planet" suggests that the speaker believes that this product is the best one available. As a result, it can also be assumed that the speaker tries to express his/her pride on this product or state that this product is good through this sentence. This condition matches an expressive illocutionary act called "boast". According to Searle (1985), "boast" only requires that the speaker believes what he/she say. In other words, it is not necessarily has to be the fact (although it can also be the fact).

2) THE BEST GAMING WEAPONS AT HAND (MSI GAMING MOTHERBOARD) (PC Powerplay, February 2014, p. 108)

Motherboard is the main circuit board of a microcomputer. The motherboard contains the connectors for attaching additional boards. Typically, the motherboard contains the CPU, BIOS, memory, mass storage interfaces, serial and parallel ports, expansion slots, and all the controllers required to control standard peripheral devices, such as the display screen, keyboard, and disk drive. Collectively, all these chips that reside on the motherboard are known as the motherboard's chipset. (Beal, n.d.)

This advertisement uses the phrase "Most Powerful" to attract consumer's ego that always want to win in everything, including in playing games. When consumers play games, they will always want to win. To win, people need best equipment or "weapon". This advertisement is expected to convince consumers that the product is the best "weapon" that they need.

Assertive: To get better understanding of its message, this sentence may be paraphrased into "This product is the best equipment for gaming that you can get." This statement may be seen as an effort to convince the readers that this product is truly the best motherboard for gaming computer that they can get, although there is no proof for that statement. This condition matches "claim" act, which defined by MerriamWebster Dictionary (2015) as "to say that (something) is true when some people may say it is not true". The "claim" act is included in assertive illocutionary act, therefore it may be concluded that this sentence carries assertive illocutionary act.

Expressive: The word "Best" commonly used to express pride or to state something is good. Based on the usage of the word, it can be concluded that the speaker tries to express his/her pride on this product or state that this product is good, and therefore matches an illocutionary act called "boast", which is included into expressive illocutionary force.

3) SUPERIOR REVOLUTION, EXTREME EFFICIENCY (REVOLUTION XT POWER 
SUPPLY) (Computer Power User, February 2014, p. 84)

Power supply, which can be also called a power supply unit or PSU, is the component that supplies power to a computer. Most personal computers can be plugged into standard electrical outlets. The power supply then pulls the required amount of electricity and converts the $\mathrm{AC}$ current to DC current. It also regulates the voltage to eliminate spikes and surges common in most electrical systems. (Beal, n.d.)

This advertisement uses the phrase "Extreme Efficiency" to raise consumer's awareness and attract them towards more efficient products. After getting their attention with this advertisement, producers expect the consumers to think that efficient product is better and they will buy such products. By using the phrase "Extreme Efficiency", the advertisement tries to tell the consumers that this product is really efficient. Using "Superior Revolution", the advertisement wants to tell the consumers that this product is "revolutionary" (new, never seen before). Generally, people want new products that never seen before, so that they will be the first to try it.

Assertive: To get a better understanding, this sentence may be paraphrased into "This product has better efficiency and more revolutionary than other products". This statement may be seen as an effort to convince the readers that this product is really revolutionary and more efficient than other similar products, although there is no proof for that statement. This condition matches "claim" act, which defined by Merriam-Webster Dictionary (2015) as "to say that (something) is true when some people may say it is not true". The "claim" act is included in assertive illocutionary act, therefore it may be concluded that this sentence carries assertive illocutionary act.
Expressive: Some phrases are used to state that this product is good ("Superior Revolution" and "Extreme Efficiency"). Based on the choice of words of the phrases in this sentence, it can be assumed that the speaker expresses his/her pride towards the product through this sentence, thus the sentence has "boast" illocutionary act, which is included into expressive illocutionary act.

\section{b. Directive-Expressive}

From 40 advertisements that had been analyzed, 15 of them contain directive- expressive type ofillocutionary force. Two of them are explained below.

4) EXPERIENCE THE MOST POWERFUL GAMING AUDIO ON THE PLANET (CREATIVE AUDIO) (Computer Power User, December 2013, pg. 79)

Headphones (or "head-phones" in the early days of telephony and radio) are a pair of small loudspeakers that are designed to be held in place close to a user's ears. They are also known as earspeakers, earphones or, colloquially, cans. The alternate in-ear versions are known as earbuds or earphones. In the context of telecommunication, a headset is a combination of headphone and microphone. Headphones either have wires for connection to a signal source such as an audio amplifier, radio, CD player, portable media player, mobile phone, video game consoles, electronic musical instrument, or have a wireless device, which is used to pick up signal without using a cable. (Wikipedia, 2015)

This advertisement uses the phrase "Most Powerful" in order to convince the consumers that the product is good. To get best audio output, the output device has to be able to handle the complicated and big input from the device. By using words "the most powerful", the advertisement tries to tell the consumer that this product will be able to handle such input and deliver best output. 
Directive: The first word of this sentence (Experience) is a basic form verb. In English grammar, the sentence that starts with a basic form of verb is an imperative sentence, which the main purpose is to express a request, command, or advice (Nordquist, 2014). Based on this condition, it can be concluded that this sentence has directive illocutionary force. Since there is no urgency or hierarchy order shown here, it does not have to be obeyed, and there is no particular interest shown, it can be suggested that this sentence carries the "suggest" illocutionary act, which is a weak form of directive.

Expressive: Usage of phrase "Most Powerful" and "on the Planet", suggests that the speaker intends to state that this product is the most powerful one in the world. Therefore, it can be assumed that the speaker tries to express his/her pride on this product or state that this product is good, and therefore matches "boast" illocutionary act, which is included into expressive illocutionary force.

5) GEAR UP AND TAKE COMMAND WITH XPG (ADATA XPG V2 DDR3 DRAM MODULE) (Computer Power User, January 2014, p. 26)

Dynamic random access memory (DRAM) is the most common kind of random access memory (RAM) for personal computers and workstations. The network of electricallycharged points in which a computer stores quickly accessible data in the form of $0 \mathrm{~s}$ and $1 \mathrm{~s}$ is called memory. Random access means that the PC processor can access any part of the memory directly rather than having to proceed sequentially from some starting places. DRAM is dynamic in that, unlike static RAM (SRAM), it needs to have its storage cells refreshed or given a new electronic charge every few milliseconds. (Rouse, 2005)
This advertisement uses the words "Gear Up" and "Take Command" in order to attract consumer's ego that always want to "take command" or dominate in everything. Generally, if someone wants to dominate something, they will not be able to do it unless they have something special. This advertisement tries to tell the consumers that if you "gear up" or use this product, you will be able to dominate everything.

Directive: Phrasal verb "Gear Up" that exists in the front of the sentence suggests that this is an imperative sentence, which aims to express a request, command, or advice (Nordquist : 2014). Therefore, this sentence has directive illocutionary force. Since there is no urgency or hierarchy order shown here, it does not have to be obeyed, and there is no particular interest shown, so it suggests that this sentence carries the "suggest" illocutionary act, which is a weak form of directive.

Expressive: There is a phrase ("Take Command") in the sentence. In common perception, to "take command" is the same to "be the leader". Further, "be the leader" can also be understood as "be the best", since in common perception, the leader of a group is usually the best one of them. In that matter, it can be suggested that this sentence can also be mean "Gear up and be the best with XPG". Based on the choice of words of this sentence, it can be assumed that this sentence carries "boast" illocutionary act, which included in assertive illocutionary force.

\section{CONCLUSION}

In short, it can be concluded that there are two illocutionary force patterns that can be found in computer products advertisements, namely assertiveexpressive and directive-expressive, each with their own way to attract consumers. 


\section{BIBLIOGRAPHY}

Justová, Veronika. Direct and Indirect Speech Acts in English. Unpublished bachelor thesis. Brno: Masaryk University, 2006, Print.

Lubis, Tania Fatima. Perbandingan Pembentukan Imej Merek Melalui Iklan Dan Event Dengan Berfokus Pada Imej Merek Sampoerna A Mild. Unpublished graduating paper. Depok: Universitas Indonesia, 2007, Print.

Levinson, Stephen C. Pragmatics. Melbourne: Cambridge University Press, 1985, Print.

Shimp, Terence A. Periklanan Promosi Aspek Tambahan Komunikasi Pemasaran Terpadu. Erlangga: Jakarta, 2003, Print.

Searle, John R. and Daniel Vanderveken. Foundation of Illocutionary Logic. Melbourne: Cambridge University Press, 1985, Print.

\section{Website}

Beal, Vangie. Motherboard. Webopedia.com, n.d. Web. Accessed in January 7, 2015.
Beal, Vangie. NAS - Network Attached Storage. Webopedia.com, n.d. Web. Accessed in January 7, 2015.

Beal, Vangie. Power Supply. Webopedia.com, n.d. Web. Accessed in January 7, 2015.

Claim. Merriam-webster.com. 2015. Web. Accessed in January 28, 2015

Headphones. Wikipedia.org, January 7, 2015. Web. Accessed in January 7, 2015.

Imam, Nang. Pengertian VGA Dan Fungsi VGA Komputer. Blogspot.com, January 16, 2014. Web. Accessed in January 7, 2015.

Rouse, Margaret. DRAM (dynamic random access memory). searchstorage.techtarget.com, September 2005. Web. Accessed in January 7, 2015.

What is a Speech Act? Center for Advanced Research on Language Acquisition (CARLA). University of Minnesota, January 22, 2015. Web. Accessed in January 28, 2015. 